\title{
Hysteroscopic evaluation in infertility and abnormal uterine bleeding
}

\author{
Navneet Kaur ${ }^{1}$, Ruby Bhatia ${ }^{2 *}$, Paramjit Kaur ${ }^{2}$, Surinder K. Bhopal ${ }^{2}$
}

\begin{abstract}
${ }^{1}$ Department of Obstetrics and Gynecology, SGL Charitable Hospital, Subhanpur Kapurthala, Punjab, India
${ }^{2}$ Department of Obstetrics and Gynecology, Government Medical College Patiala, Punjab, India
\end{abstract}

Received: 29 November 2017

Accepted: 26 December 2017

\author{
*Correspondence: \\ Dr. Ruby Bhatia, \\ E-mail: drrubybhatia@yahoo.com
}

Copyright: (C) the author(s), publisher and licensee Medip Academy. This is an open-access article distributed under the terms of the Creative Commons Attribution Non-Commercial License, which permits unrestricted non-commercial use, distribution, and reproduction in any medium, provided the original work is properly cited.

\begin{abstract}
Background: Hysteroscopy an endoscopic procedure for visualization of uterine cavity may be extensively used in both primary and secondary infertility and abnormal uterine bleeding for evaluating intrauterine pathology. The objectives of this study were to visualize and identity intrauterine pathology in both primary and secondary infertility and abnormal uterine bleeding (AUB) by hysteroscopic evaluation and to perform hysteroscopic guided therapeutic procedures like endometrial currettage, polypectomy, adhesiolysis.

Methods: Hysteroscopic evaluation of uterine cavity for any intrauterine pathology in AUB and Infertility. Adhesiolysis, polypectomy, endometrial biopsy misplaced copper $\mathrm{T}$ removal were carried out under hysteroscopic vision.

Results: Intrauterine synechia in $20.51 \%$, Submucous fibroid in $5.13 \%$, bicornuate uterus, endometrial hyperplasia and endometrial polyp were seen in $2.56 \%$ patient each were detected in infertility group while $81.95 \%$ cases with AUB had abnormal intrauterine pathology commonest being endometrial hyperplasia in $33.33 \%$ followed by endometrial polyps in $23.81 \%$ cases, submucous fibroid and misplaced copper $\mathrm{T}$ in $9.52 \%$ each and intrauterine synechia in $4.76 \%$ patient. Endometrial biopsy and polypectomy was done in $23.80 \%$ each with AUB, misplaced copper T removal in $9.52 \%$ and adhesiolysis in $4.76 \%$ patient with AUB.

Conclusions: Hysteroscopy remains gold standard for evaluating intrauterine lesions in abnormal uterine bleeding and infertility. A safe, simple minimally invasive procedure not only diagnostic but therapeutic modality for adhesiolysis, endometrial biopsy/curettage, polypectomy, misplaced copper $\mathrm{T}$ removal under direct vision with minimal complication within reach of every Gynaecologist thereby reducing burden of major surgical intervention.
\end{abstract}

Keywords: Abnormal uterine bleeding, Hysteroscopy, Primary infertility, Secondary infertility

\section{INTRODUCTION}

Hysteroscopy an endoscopic procedure for visualization of uterine cavity is extensively used in gynaecological disorders like abnormal uterine bleeding, infertility both primary and secondary and post-menopausal bleeding. ${ }^{1}$ Hysteroscopy is the current gold standard for evaluating intrauterine pathology including submucous myomas, endometrial polyps, endometrial hyperplasia and endometrial cancer. ${ }^{2}$ Though major role of outpatient hysteroscopy in abnormal uterine bleeding is diagnostic there is a scope for simple operative procedures such as targeted endometrial biopsy, polypectomy compared with random sampling where small intrauterine lesions can be easily missed. Thus accurate diagnosis of abnormal uterine bleeding helps in choosing appropriate treatment there by avoiding unnecessary major surgical interventions. ${ }^{3,4}$ It can reduce burden of major surgical intervention in AUB which may be treated by simple hysteroscopic guided procedures. ${ }^{4}$ Hysteroscopy should be considered early in the diagnostic work up of patients with unexplained infertility, recurrent implantation 
failure, recurrent pregnancy loss and abnormal uterine bleeding due to high rate of intra uterine pathology in these women. Hysteroscopy not only remains diagnostic modality but is accurate, safe, effective and preferred method of treatment for uterine synechie, uterine septum, endometrial polyps and uterine myomas thereby enhancing fertility, subsequent pregnancy rate and reproductive performance..$^{5}$ Hysteroscopy is safe, well tolerated endoscopic technique with high accuracy in detecting intrauterine pathology in various gynecological disorders. ${ }^{6}$ Post procedure Pain and uterine perforation remain some of the complications. It is minimally invasine simple and safe approach for intrauterine evaluation with very low rate of complications.

The aim and objectives of this study were to study hysteroscopic evaluation of uterine cavity so as to identify intrauterine pathology in infertility both primary as well as secondary and abnormal uterine bleeding and to perform hysteroscopic guided therapeutic procedures like endometrial biopsy/curettage, polypectomy, adhesiolysis and to ascertain any major or minor complications of hysteroscopy.

\section{METHODS}

A total of 60 patients between 20-59 years of age with Abnormal uterine bleeding or primary/secondary infertility were selected from outpatient Department of Obstetrics and Gynaecology, Government Medical College, Rajindra Hospital Patiala from January 2013 to June 2014.

Patients were counselled regarding Hysteroscopic evaluation of uterine cavity. A detailed history, general physical and local examination to know size of uterus, mobility, any adenaxal pathology was done in every case. Hemoglobin, bleeding and clotting time, complete urine, ESR, HBsAg, HCV and HIV were done in all cases.

Special investigations for infertility as required were also done. Women with pregnancy, acute reproductive tract infections, genital tuberculosis, salpingits, cardiopulmonary disorders and cervical cancer were excluded from the study. Hysteroscopic evaluation of uterine cavity was done under General anesthesia with four mm diameter rigid telescope with Hopkins rod lens optical system. Normal saline was used as distending media. Hysteroscope with operative accessories, light source, image recorder and camera were part of the unit in use.

Hysteroscope with its sheath and operative accessories was presterilized in cidex solution (gluteraldehyde 2\%) for one hour. Hysteroscopic procedure under general anesthesia done with patient in lithotomy position after evacuating bladder under complete asepsis. Posterior vaginal wall retracted with sims speculum. Anterior lip of cervix held with tenaculum so that it does not interfere with introduction of hysteroscope. Exploration of uterine cavity begin at the level of internal OS. Further entire uterine cavity was inspected. Both tubal ostia visualized and any pathology in uterine cavity such as intrauterine adhesions, uterine septum, endometrial hyperplasia or polyp, submucous fibroid noted. Simple operative procedures like adhesiolysis, polypectomy, Endometrial curettage or forgotten/misplaced copper-Tremoval under hysteroscopic vision were carried out wherever possible. Endocervical canal was visualized as the hysteroscope was being withdrawn. Results of hysteroscopy noted and correlated with clinical findings. Hysteroscopy was combined with laparoscopy and chromopertubation in patients with primary and secondary infertility.

\section{RESULTS}

Majority of patients, 29 (48.33\%) were in 20-29 years of age, $40 \%$ (24) patients were in age group of 30-39 years while only one patient $(1.67 \%)$ was post-menopausal above 50 years (Table 1 ).

Table 1: Distribution of patients according to sociodemographic profile.

\begin{tabular}{|c|c|c|c|c|c|c|c|}
\hline Age in years & \multicolumn{3}{|c|}{ No. of Patients } & \multicolumn{4}{|c|}{ Percentage } \\
\hline $20-29$ & \multicolumn{3}{|c|}{29} & \multicolumn{4}{|c|}{48.33} \\
\hline $30-39$ & \multicolumn{3}{|l|}{24} & \multicolumn{4}{|c|}{40} \\
\hline $40-49$ & \multicolumn{3}{|l|}{6} & \multicolumn{4}{|l|}{10} \\
\hline $50-59$ & \multicolumn{3}{|l|}{1} & \multicolumn{4}{|c|}{1.67} \\
\hline Total & \multicolumn{3}{|l|}{60} & \multicolumn{4}{|c|}{100} \\
\hline $\begin{array}{l}\text { Age in } \\
\text { years }\end{array}$ & \multicolumn{7}{|c|}{$\begin{array}{l}\text { Min age: } 20 \text {; Max age: } 59 \text {; Mean age: } \\
\text { 31.88; Std. deviation: } 7.67\end{array}$} \\
\hline \multicolumn{8}{|l|}{ Residence } \\
\hline Rural & \multicolumn{3}{|l|}{32} & \multicolumn{4}{|c|}{53.33} \\
\hline Urban & \multicolumn{3}{|l|}{28} & \multicolumn{4}{|c|}{46.67} \\
\hline Total & \multicolumn{3}{|l|}{60} & \multicolumn{4}{|c|}{100} \\
\hline \multicolumn{8}{|l|}{ Occupation } \\
\hline Homemaker & \multicolumn{3}{|l|}{44} & \multicolumn{4}{|c|}{73.33} \\
\hline Govt. job & \multicolumn{3}{|l|}{6} & \multicolumn{4}{|c|}{10.00} \\
\hline Private job & \multicolumn{3}{|l|}{10} & \multicolumn{4}{|c|}{16.67} \\
\hline Total & \multicolumn{3}{|l|}{60} & \multicolumn{4}{|c|}{100} \\
\hline \multirow[t]{2}{*}{ Parity } & \multirow[t]{2}{*}{ No. } & \multirow[t]{2}{*}{$\%$} & \multicolumn{5}{|c|}{$\begin{array}{l}\text { History of abortions if } \\
\text { any }\end{array}$} \\
\hline & & & A0 & A1 & A2 & A3 & A4 \\
\hline P0 & 28 & 46.66 & 22 & 4 & 1 & - & 1 \\
\hline $\mathrm{P} 1$ & 9 & 15 & 2 & 4 & 2 & 1 & - \\
\hline $\mathrm{P} 2$ & 15 & 25 & 12 & 2 & 1 & - & - \\
\hline P3 & 8 & 13.33 & 7 & - & 1 & - & - \\
\hline Total & 60 & 100 & 43 & 10 & 5 & 1 & 1 \\
\hline
\end{tabular}

Mean age in the present study was $31.88 \pm 7.67$ years. Majority of patients in the present study 32 (53.33\%) were from rural areas. Majority of patients in the present study $44(73.33 \%)$ were homemakers. $16.67 \%$ (10) in private job and only $6(10 \%)$ in government job. 28 $(46.67 \%)$ patients were nullipara, $22(36.67 \%)$ of them presented with primary infertility. One patient in nullipara group had history of recurrent abortions (Four consecutive abortions). A total of $32(53.33 \%)$ patients were multiparous. Nine $(15 \%)$ of them were para 1. 
Among para 1, two patients had history of consecutive two abortions while one patient had recurrent abortions (three consecutive abortions). Thus two (3.33\%) patients in the present study had history of recurrent spontaneous abortions i.e. three/ four abortions (Table 1).

A total of $39(65 \%)$ patients presented with infertility and $21(35 \%)$ presented with abnormal uterine bleeding (Table 2). 22 patients $(56.41 \%)$ presented with primary infertility while $17(43.59 \%)$ presented with secondary infertility (Table 2). In patients with menstrual irregularity/AUB $13(61.9 \%)$ had menorrhagea. Four $(19.04 \%)$ presented with metrorrhegia. One Patient $(4.76 \%)$ came with post-menopausal bleeding. Two patients $(9.52 \%)$ had polymenorrhegea while one $(4.76 \%)$ patient presented with oligomenorrhoea (Table 2).

Table 2: Distribution of patients according to presenting complaint n-60.

\begin{tabular}{|lll|}
\hline Presenting complaint & No. of patient & $\%$ \\
\hline Infertility & 39 & 65 \\
\hline Abnormal Uterine bleeding & 21 & 35 \\
\hline Total & 60 & 100 \\
\hline Infertility & & \\
\hline Primary Infertility & 22 & 56.41 \\
\hline Secondary Infertility & 17 & 43.59 \\
\hline Total & 39 & 100 \\
\hline Abnormal uterine bleeding & & \\
\hline Menorrhagia & 13 & 61.90 \\
\hline Metrorrhagia & 4 & 19.04 \\
\hline Polymenorrhagia & 2 & 9.52 \\
\hline Post-menopausal bleeding & 1 & 4.76 \\
\hline Oligo menorrhea & 1 & 4.76 \\
\hline Total & 21 & 100 \\
\hline
\end{tabular}

Duration of infertility in majority of patients i.e. 11 $(50 \%)$ in primary infertility and $13(76.47 \%)$ in secondary infertility was between 1-5 years. Duration of infertility in $9(40.90 \%)$ patients with primary and three $(17.65 \%)$ patients with secondary infertility ranged between 6 to 10 years. One patient each in both groups had infertility for more than 15 years (Table 3). Majority of patients i.e. 17 (80.95\%) in Abnormal uterine bleeding group had symptoms ranging from 1-6 months while only four (19.05\%) cases had duration of symptoms for more than 6 months (Table 3).

Table 3: Distribution of patients in relation to duration of symptoms.

\begin{tabular}{|lcl|}
\hline $\begin{array}{l}\text { Duration in years } \\
\text { Primary Infertility }\end{array} \mathbf{n = 2 2}$ & No patients & $\%$ \\
\hline $1-5$ & 11 & 50 \\
\hline $6-10$ & 9 & 40.90 \\
\hline $11-15$ & 1 & 4.55 \\
\hline$>15$ & 1 & 4.55 \\
\hline Total & 22 & 100 \\
\hline Secondary infertility & $\mathbf{n}$ & \\
\hline $1-5$ & 13 & 76.47 \\
\hline $6-10$ & 3 & 17.65 \\
\hline $11-15$ & - & - \\
\hline$>15$ & 1 & 5.88 \\
\hline Total & 17 & 100 \\
\hline Abnormal uterine bleeding $\mathbf{n}=\mathbf{2 1}$ & \\
\hline $1-6$ months & 17 & 80.95 \\
\hline$>6$ months & 4 & 19.05 \\
\hline Total & 21 & 100 \\
\hline
\end{tabular}

Majority of patient $26(66.67 \%)$ with infertility had normal uterine cavity while intra uterine abnormality was detected in $13(33.33 \%)$ patients only.

The commonest abnormality detected was intrauterine adhesions in $8(20.51 \%)$ patients followed by submucous fibroid in two $(5.13 \%)$ cases. Bicornuate uterus, endometrial hyperplasia and endometrial polyp were reported in one $(2.56 \%)$ patient each in women with infertility (Table 4). Out of 22 cases with primary infertility, majority $14(63.64 \%)$ had normal uterine cavity, seven $(31.82 \%)$ patients had intrauterine adhesions and one patient $(4.54 \%)$ had endometrial polyp where as in secondary infertility group with total 17 cases, $12(70.59 \%)$ patients had normal uterine cavity, two $(11.76 \%)$ patients had submucous fibroid while bicornate uterus, intrauterine adhesions and endometrial hyperplasia was reported in one $(5.88 \%)$ patient each on hysteroscopy. Seven patients of primary infertility with intrauterine synechia were further evaluated extensively for genital koch's (Table 4).

Table 4: Hysteroscopic findings in patients with infertility $N=39$.

\begin{tabular}{|llllllll|}
$\begin{array}{l}\text { Clinical } \\
\text { findings }\end{array}$ & $\begin{array}{l}\text { No. of } \\
\text { cases }\end{array}$ & $\begin{array}{l}\text { Normal } \\
\text { uterine cavity }\end{array}$ & $\begin{array}{l}\text { Intrauterine } \\
\text { adhesions }\end{array}$ & $\begin{array}{l}\text { Submucous } \\
\text { fibroid }\end{array}$ & $\begin{array}{l}\text { Bicornuate } \\
\text { uterus }\end{array}$ & $\begin{array}{l}\text { Endometrial Endometrial } \\
\text { hyperplasia }\end{array}$ & $\begin{array}{l}\text { Endyp } \\
\text { Polyp }\end{array}$ \\
\hline Primary infertility & 22 & $14(63.64 \%)$ & $7(31.82 \%)$ & - & - & & $1(4.54 \%)$ \\
\hline Secondary infertility & 17 & $12(70.59 \%)$ & $1(5.88 \%)$ & $2(11.76 \%)$ & $1(5.88 \%)$ & $1(5.88 \%)$ & - \\
\hline Total & 39 & $261(66.67 \%)$ & $8(20.51 \%)$ & $2(5.13 \%)$ & $1(2.56 \%)$ & $1(2.56 \%)$ & $1(2.56 \%)$ \\
\hline
\end{tabular}

In patients with abnormal uterine bleeding/menstrual irregularity only $19.05 \%$ (4 cases) had normal uterine cavity on hysteroscopy while $81.95 \%$ (17) patients had one or other intrauterine abnormality detected on hysteroscopy (Table 5). Endometrial hyperplasia was present in seven $(33.33 \%)$ cases, endometrial polyps were 
detected in five $(23.81 \%)$ cases. Submucous fibroid and misplaced/forgotten copper $\mathrm{T}$ were reported in two $(9.52 \%)$ cases each. One case $(4.76 \%)$ with Oligomenorrhea was diagnosed with intrauterine adhesions. Endometrial hyperplasia was reported in two cases with menorrhagia, three cases with metrorrhagia and 2 cases with polymenorrhagia respectively while three patients with menorrhagia and two patients with metrorrhagia showed endometrial polyps respectively.

Table 5: Hysteroscopic findings in abnormal uterine bleeding $\mathbf{n = 2 1}$.

\begin{tabular}{|lllllllll|}
\hline Clinical Findings & $\begin{array}{l}\text { No. of } \\
\text { cases }\end{array}$ & $\begin{array}{l}\text { Normal } \\
\text { uterine } \\
\text { cavity }\end{array}$ & $\begin{array}{l}\text { Abnormal } \\
\text { Findings }\end{array}$ & $\begin{array}{l}\text { Endometrial } \\
\text { hyperplasia }\end{array}$ & $\begin{array}{l}\text { Endometrial } \\
\text { polyp }\end{array}$ & $\begin{array}{l}\text { Submucous } \\
\text { fibroid }\end{array}$ & $\begin{array}{l}\text { Misplace } \\
\text { CuT }\end{array}$ & $\begin{array}{l}\text { Intrauterine } \\
\text { adhesion }\end{array}$ \\
\hline Menorrhagia & 13 & 4 & 9 & 2 & 3 & 2 & 2 & - \\
\hline $\begin{array}{l}\text { Metrorrhagia } \\
\text { Post-menopausal } \\
\text { bleeding }\end{array}$ & 4 & - & 4 & 3 & 1 & - & - & - \\
\hline Polymenorrhagia & 2 & - & 1 & - & 1 & - & - & - \\
\hline Oligomenorrhea & 1 & - & 2 & 2 & - & - & - & - \\
\hline Total number & 21 & 4 & 1 & - & - & - & - & 1 \\
\hline$\%$ & 100 & $(19.05 \%)$ & $(81.95 \%)$ & $(33.33 \%)$ & $(23.81 \%)$ & $(9.52 \%)$ & $(9.52 \%)$ & $(4.76 \%)$ \\
\hline
\end{tabular}

One case with post-menopausal bleeding had evidence of endometrial polyp on hysteroscopy submucous fibroid and misplaced/forgotten copper $\mathrm{T}$ were observed in two cases each with menorrhagia (Table 5).

Out of a total 60 patients, $30(50 \%)$ cases had abnormal findings on hysteroscopic visualization of uterine cavity. Abnormal finding in AUB/menstrual irregularity group were as high as $80.95 \%$ (17 cases out of 21 ) while in infertility only 13 patients $(33.33 \%)$ depicted abnormal intrauterine findings on hysteroscopy (Table 6).
Table 6: Co-relation between clinical diagnosis and Hysteroscopy findings $\mathrm{N}=60$.

\begin{tabular}{|c|c|c|c|}
\hline \multirow[t]{2}{*}{$\begin{array}{l}\text { Clinical } \\
\text { findings }\end{array}$} & \multirow[t]{2}{*}{$\begin{array}{l}\text { No. of } \\
\text { cases }\end{array}$} & \multicolumn{2}{|c|}{ Hysteroscopic findings } \\
\hline & & Normal (\%) & Abnormal (\%) \\
\hline Infertility & 39 & $26(66.67 \%)$ & $13(33.33 \%)$ \\
\hline AUB & 21 & $4(19.05 \%)$ & $17(80.95 \%)$ \\
\hline Total & 60 & $30(50 \%)$ & $30(50 \%)$ \\
\hline
\end{tabular}

Table 7: Hysteroscopy directed operative procedures $\mathbf{N}=\mathbf{6 0}$.

\begin{tabular}{|c|c|c|c|c|c|c|c|c|c|c|c|c|}
\hline \multirow{3}{*}{$\begin{array}{l}\text { Clinical } \\
\text { Diagnosis }\end{array}$} & \multicolumn{12}{|c|}{ Operative Procedures } \\
\hline & \multirow[t]{2}{*}{$\mathbf{N}$} & \multirow[t]{2}{*}{$\%$} & \multicolumn{2}{|c|}{ Copper removal } & \multicolumn{2}{|c|}{ Endometrial curettage } & \multicolumn{2}{|c|}{ Polypectomy } & \multicolumn{2}{|c|}{ Adhesiolysis } & \multicolumn{2}{|c|}{ Total } \\
\hline & & & $\mathbf{N}$ & $\%$ & $\mathbf{N}$ & $\%$ & $\mathbf{N}$ & $\%$ & $\mathbf{N}$ & $\%$ & $\mathbf{N}$ & $\%$ \\
\hline Infertility & 39 & 100 & & & 1 & 2.56 & & & & & 1 & 2.56 \\
\hline Menstrual irregular & 21 & 100 & 2 & 9.52 & 5 & 23.80 & 5 & 23.80 & 1 & 4.76 & 13 & 61.90 \\
\hline Total & 60 & 100 & 2 & 3.33 & 6 & 10.0 & 5 & 8.33 & 1 & 1.66 & 14 & 23.33 \\
\hline
\end{tabular}

Table 8: Complications of Hysteroscopy N=60\%.

\begin{tabular}{|lll|}
\hline Complication & N & $\%$ \\
\hline Uterine perforation & 0 & 0 \\
\hline Post-operative Pain & 4 & 6.67 \\
\hline Spotting per vaginun & 3 & 5 \\
\hline
\end{tabular}

Post-operative pain relieved by analgesics was reported in $4(6.67 \%)$ cases. Three $(5 \%)$ patients had spotting per vaginum which stopped without any medication. None of the cases in the present study reported uterine perforation or any other major complication (Table 8).

\section{DISCUSSION}

The present study was carried out to diagnose intrauterine causes by Hysterescopic evaluation in primary/secondary infertility and abnormal uterine bleeding (AUB). In the present study majority of patients $48.33 \%$ were in age group of 20-29 years followed by $40 \%$ between $30-39$ 
years, $10 \%$ between $40-49 \%$ years and $1.67 \%$ between 50-59 years. Patil and Daver reported $48 \%$ in 30-39 years age group, $32 \%$ in $40-49$ years and $8 \%$ in $50-59$ years while only $12 \%$ in $20-29$ years as he only included patients with AUB while present study had higher number of young patients with infertility. ${ }^{9}$

In study conducted by Dewit et al, $31 \%$ patients were nulliparous while $69 \%$ were primiparous or multiparas while in the present study $46.67 \%$ were nulliparous and $53.33 \%$ primipara or multipara. The difference again is due to higher number of younger patients with infertility in the present study. ${ }^{10}$ Kapur and Biswas reported normal intrauterine cavity in $49 \%$ cases of infertility while Nawroth F et al reported no pathology in $89.9 \%$ cases respectively. ${ }^{11,12}$ In the present study intra uterine adhesions were commonest finding on hysteroscopy in infertility. Sheriar et al in hysteroscopic evaluation of infertility also reported intrauterine adhesions as commonest lesion in $20 \%$ of patients similar to the present study (Table 9). ${ }^{13}$

Table 9: Hysteroscopic findings in patients with Infertility in various studies.

\begin{tabular}{|c|c|c|c|c|c|c|c|c|}
\hline \multirow{2}{*}{$\begin{array}{l}\text { Author and } \\
\text { year of } \\
\text { study }\end{array}$} & \multicolumn{8}{|c|}{ Abnormality detected on hysteroscopy in patients with infertility } \\
\hline & $\begin{array}{l}\text { Intra } \\
\text { uterine } \\
\text { adhesion }\end{array}$ & $\begin{array}{l}\text { Sub- } \\
\text { mucous } \\
\text { fibroid }\end{array}$ & $\begin{array}{l}\text { Endometrial } \\
\text { polyp }\end{array}$ & $\begin{array}{l}\text { Endometrial } \\
\text { hyperplasia }\end{array}$ & $\begin{array}{l}\text { Bicornuate } \\
\text { uterus }\end{array}$ & Septum & Petechiae & $\begin{array}{l}\text { Irregular } \\
\text { cavity }\end{array}$ \\
\hline Sheriar et al & $20(20 \%)$ & $3(3 \%)$ & $10(10 \%)$ & - & - & $7(7 \%)$ & - & - \\
\hline Parkash et al & $7(14 \%)$ & $2(4 \%)$ & $2(4 \%)$ & - & - & $3(6 \%)$ & - & - \\
\hline $\begin{array}{l}\text { Kapur and } \\
\text { Biswas }\end{array}$ & \multicolumn{3}{|c|}{$39(36.1 \%)$} & $14.81 \%$ & & & & \\
\hline Present study & $\begin{array}{l}8 \\
(20.51 \%)\end{array}$ & $\begin{array}{l}2 \\
(5.13 \%)\end{array}$ & $1(2.5 \%)$ & $1(2.56 \%)$ & $1(2.56 \%)$ & - & - & - \\
\hline
\end{tabular}

Table 10: Abnormality detected on Hysteroscopy in abnormal uterine bleeding in various studies.

\begin{tabular}{|c|c|c|c|c|c|c|c|}
\hline \multirow[t]{2}{*}{ Series } & \multicolumn{7}{|c|}{ Abnormality detected on hysteroscopy in patient of AUB } \\
\hline & $\begin{array}{l}\text { Endometrial } \\
\text { hyperplasia }\end{array}$ & $\begin{array}{l}\text { Endometrial } \\
\text { polyp }\end{array}$ & $\begin{array}{l}\text { Atrophic } \\
\text { endometrium }\end{array}$ & $\begin{array}{l}\text { Sub- mucous } \\
\text { leiomyoma }\end{array}$ & $\begin{array}{l}\text { Intra uterine } \\
\text { adhesions }\end{array}$ & $\begin{array}{l}\text { Intra uterine } \\
\text { device }\end{array}$ & Septum \\
\hline $\begin{array}{l}\text { Motashaw and } \\
\text { Dave }\end{array}$ & $85(22.97 \%)$ & $76(21.53 \%)$ & $6(1.62 \%)$ & $42(11.35 \%)$ & $21(5.67 \%)$ & $5(1.4 \%)$ & - \\
\hline $\begin{array}{l}\text { Patil and } \\
\text { Daver }\end{array}$ & $15(33.3 \%)$ & $7(15.6 \%)$ & $2(4.4 \%)$ & $3(6.66 \%)$ & $1(2.2 \%)$ & - & - \\
\hline De Wit et al & - & $13.5 \%$ & - & $20.1 \%$ & $4.5 \%$ & - & $1.9 \%$ \\
\hline Zlatkov et al & $45.34 \%$ & & - & - & - & - & - \\
\hline Present Study & $7(33.33 \%)$ & $5(23.81 \%)$ & - & $2(9.52 \%)$ & $1(4.76 \%)$ & $2(9.52 \%)$ & - \\
\hline
\end{tabular}

He reported submucous leiomyoma as cause in $3 \%$ while we reported submucous leiomyoma in $5.13 \%$ cases of infertility. Endometrial polyps were seen in $10 \%$ cases while in present study only $2.5 \%$ patients with infertility had endometrial polyp. Uterine septum as a cause of infertility was reported by Sheriar et al and Parkash et al in $7 \%$ and $3 \%$ respectively while none of our case of infertility had uterine septum. ${ }^{13,14}$ Intrauterine adhesion as high as $36.1 \%$ and other uterine abnormalities in $14.81 \%$ as a cause of infertility was reported by Kapur and Biswas. $^{11}$ None of the studies reported endometrial hyperplasia in infertility while one patient $(2.56 \%)$ in the present study had endometrial hyperplasia, she was diagnosed as PCOS (Table 9).

Endometrial hyperplasia was the most common (33.33\%) abnormality in patients with menstrual irregularity in present study as observed by Motashaw, Patil and Daver, and Zlatkov et al. ${ }^{9,15,16}$ Endometrial polyp was the second most common intrauterine lesion $(23.81 \%)$ as a causes of AUB in the present study which is similar to as observed by Motashaw and Dave $21.53 \%$, Daver P (15.6\%) and $13.5 \%$ by de wit et al. ${ }^{9,10,15}$ Submucous fibroid in AUB were seen in $9.52 \%$ patients in the present study which is comparable with $11.35 \%$ detected by Motashaw and Dave. ${ }^{15}$ Misplaced forgotten copper $\mathrm{T}$ was detected in $9.52 \%$ cases in the present study where as it was detected in $5(1.4 \%)$ cases by Metashaw and Dave. ${ }^{15}$

We observed intrauterine adhesions in $4.76 \%$ (one) patient with AUB. Intrauterine adhesions were observed in $2.2 \%, 4.5 \%$ and $5.6 \%$ cases respectively by other authors also (Table 10)..$^{9,10,15}$ Appropriate therapeutic procedures under hysteroscopic vision were carried out where ever possible. Out of 21 patients with AUB, 5 patients $(23.80 \%)$ underwent endometrial curettage, five 
patients $(23.80 \%)$ had polypectomy. Misplaced or forgotten Copper $\mathrm{T}$ removed under hysteroscopic vision in two $(9.52 \%)$ patients. Adhesiolysis was done in one $(4.76 \%)$ patient with oligomenorrhea. In infertility group one patient $(2.56 \%)$ with endometrial hyperplasia underwent endometrial curettage (Table 7).

Only minor complications in form of post procedure pain in $4(6.67 \%)$ cases and spotting in $3(5 \%)$ were seen in the present study. Shveiky et al reported uterine perforation in $7 \%$, infection in $1 \%$ and anaesthesia related complications in $0.5 \% .^{7}$ No such complications were reported in present study.

\section{CONCLUSION}

Hysteroscopy should be considered early in diagnostic work up of both primary as well as secondary infertility and Abnormal uterine bleeding. It remains gold standard for evaluation in abnormal uterine bleeding with hysteroscopic directed endometrial biopsy at same sitting. It is not only a diagnostic but therapeutic modality for adhesiolysis in intrauterine synechie, endometrial biopsy/curettage in endometrial hyperplasia, polypectomy under direct vision for endometrial polyps and removal of misplaced/forgotten copper $\mathrm{T}$.

A simple procedure with minimal post procedure pain which every gynecologist can learn. Hysteroscopy is minimally invasive, a safe approach for evaluation of intrauterine lesions in primary as well as secondary infertility and AUB with minimal complications. Targetted endometrial biopsy/ curettage under hysteroscopic vision provides better diagnostic modality compared to random sampling where a small intrauterine lesion may be missed. It can reduce burden of major surgical intervention in AUB which may be treated by simple hysteroscopic guided procedures. Hysteroscopy is a necessary tool in the armanentarium of Gynaecological endoscopic surgery.

Funding: No funding sources

Conflict of interest: None declared

Ethical approval: The study was approved by the Institutional Ethics Committee

\section{REFERENCES}

1. Dongar VH, d kroon CD, Jacobi CE, Trimbos JB Jansen FW. Diagnostic hysteroscopy in abnormal uterine bleeding: a systematic review and metaanalysis. BJOG. 2007;114(6):664-75.

2. Bakour SH, Jones SE, O' Donovan P. Ambulatory hysteroscopy; evidence based guide to diagnosis and therapy. Best Pract Res Clin Obstet Gynaecol. 2006;20(6):953-75.

3. Refai AMN, Anderson T, Cheah SS. Outpatient hysteroscopy: findings and decision making for treatment of abnormal uterine bleeding in pre-and post-menopausal women. Middle East Fertility Society J. 2005;10(1):43-8.

4. Guin G, Sandhu SK, Lele A, Khare S. Hysteroscopy in evaluation of abnormal uterine bleeding. J Obstet Gynaecol India. 2011;61(5):546-9.

5. Asaad AOA, Awwad AM. Hysteroscopy: the gold standard diagnostic and therapeutic tool in Gynaecology. Our experience at Queen Alia Hospital, Jordan. Middle East J Family Med. 2012;10(9):1-4.

6. Feng L, Li D. Evaluation of intrauterine disorders by hysteroscopy and transvaginal sonography. Gynaecol Endoscopy. 2002;11(6):401-4.

7. Shveiky D, Rojansky N, Ravel A, Benshushan A, Laufer N, Shushan A. Complications of hysteroscopic surgery: beyond the learning curve. J Minimally Invasive Gynaecol. 2007;14(2):218-22.

8. Sardo AD, Taylor A, Tsirkas P, Mastrogamvrakis G, Sharma M, Magos A. Hysteroscopy: a technique for all? Analysis of 5,000 outpatient hysteroscopies. Fertility and sterility. 2008;89(2):438-43.

9. Patil SK, Daver RG. Hysteroscopy in excessive uterine bleeding. J Obst Gynaecol India. 1993;43(4):605-10.

10. deWit AC, Vieugels MPH, de Kruif JH. Diagnostic hysteroscopy; a valuable diagnostic tool in the diagnosis of structural intracavital pathology and endometrial hyperplasia or Carcinoma? Eur J Obstet Gynaecol Reprod Biol. 2003;110(1):79-82.

11. Kapur K, Biswas M. Office Hysterscopy. J Obstet Gynaecol India. 2005;55(2):174-7.

12. Nawroth F, Foth D, Schmidt T. Mini hysteroscopy as routine diagnostic procedure in women with primary infertility. J Am Asso Gynaecol Laparoscopists. 2003;10(3):396-8.

13. Shereiar NK, Walvekar VR, Bhathena RK, Daftary $\mathrm{SN}$. Combined premenstural D\&C, lapro hysteroscopy in the investigation of infertility. J Obstet Gynaecol India. 1991;41(6):807-11.

14. Prakash A, Sharma K, Choudhary V. The role of hysteroscopy in evaluation of infertility. J Obstet Gynaecol India. 2000;50(6):83-5.

15. Motashaw ND, Dave S. Diagnostic and therapeutic hysteroscopy in the management of abnormal uterine bleeding. J Reprod Med. 1990;35(6):616-9.

16. Zlatkov V, Burzakov G, Cholakova A, Miloshov V, Radeva V, Velinov E, et al. Diagonostic possibilities of the flexible hysteroscopy in irregular uterine bleeding. Akush Ginekol (Sofiia). 2006;45(1):36-40.

17. Patel SG, Bhute SB, Inamdar SA, Shrivastava DS. Role of diagnostic hysteroscopy in abnormal uterine bleeding and its histopathological correlation. J Gynecol Endoscopy Surg. 2009;1(2):105-12.

Cite this article as: Kaur N, Bhatia R, Kaur P, Bhopal SK. Hysteroscopic evaluation in infertility and abnormal uterine bleeding. Int J Reprod Contracept Obstet Gynecol 2018;7:612-7. 